\title{
Biology of the crab Leurocyclus tuberculosus (H. Milne Edwards \& Lucas, 1843) bycatch from pink shrimp trawl fishery in the coast of Rio de Janeiro, Brazil
}

Tainá Stauffer, Maria Cristina Ostrovski, Tereza Cristina Gonçalves da Silva-Ferreira and Tarso Costa

Laboratório de Carcinologia, Departamento de Zoologia, Instituto de Biologia, Universidade Federal do Rio de Janeiro, Cidade Universitária, 21944-970, Rio de Janeiro, RJ, Brasil. E-mail: (TS) tainastauffer@gmail.com; (MCO) ostra@biologia.ufrj.br; (TCGSF) terezacg@biologia.ufrj.br; (TC) tarsommc@yahoo.com.br

\section{Abstract}

Trawling is known as one of less selective fishing gears and presents high index of accidental captures. The objective of this paper is to characterize the population structure, fecundity and relative growth of Leurocyclus tuberculosus often caught as bycatch in pink shrimp trawl. Sampling occurred between October 2008 and September 2009 in the coast of Rio de Janeiro State, using commercial shrimp trawl. The sample totalized 269 crabs, 168 males and 101 females (42 ovigerous). The sex ratio was 1:1.66 (M:F) and differed statistically from the expected $\left(\mathrm{X}^{2}=16.68 ; \mathrm{p}>0.05\right)$. The carapace width $(\mathrm{CW})$ ranged from 12.81 to 71.67 $\mathrm{mm}$ (mean \pm SD: $48.77 \pm 13.75 \mathrm{~mm}$ ) and from 15.33 to $55.44 \mathrm{~mm}(36.19 \pm$ $8.66 \mathrm{~mm}$ ) in males and females, respectively. The size at onset of sexual maturity was estimated at $30 \mathrm{~mm}$ (females) and $55 \mathrm{~mm}$ (males). The individual fecundity ranged from 3,450 to 23,680 eggs/brood $(10,327.3 \pm 4,827.7)$. The analysis of relative growth did not differ from the Brachyura predictions. The histogram analysis showed that shrimp trawl affects the L. tuberculosus population equally, capturing from very young individuals to adults.

Key words: Leurocyclus, spider crab, fecundity, morphometry, maturity.

\section{Introduction}

Due to its high economic value, shrimps are one of the most targeted fishery resources in Brazil and have been suffering with overfishing (Pauly et al., 2002). The seabob shrimp Xiphopenaeus kroyeri (Heller, 1862), the argentine stiletto shrimp Artemesia longinaris Bate 1888, the white shrimp Litopenaeus schmitti (Burkenroad, 1936) and the redspotted shrimps Farfantepenaeus paulensis (PérezFarfante, 1967) and F. brasiliensis (Latreille, 1817) are the most commercially exploited species in the coast of Rio de Janeiro State (Silva and Vianna, 2009).

The commercial fishing of these decapods, especially in trawls, has very poor selectivity, thus capturing a considerable amount of species known as incidental bycatch (Alverson et al., 1994). In Brazil, trawl fishery is under Ministry of Environment management, which regulates this fishing technique by laws that take into account the minimum allowed size and the reproduction period of each shrimp species (SUDEPE, 1983; 1984; MMA, 2001). However, there is still no law dealing specifically with the capture of bycatch and the 
few ones referring to the target species are not enforced (Castello, 2008).

The crab Leurocyclus tuberculosus $(\mathrm{H}$. Milne Edwards \& Lucas, 1843), an endemic American species is often caught as bycatch by shrimp trawl fishing (Roux and Piñero, 2006; Keunecke et al., 2007). It occurs in coastal Southern and Southeastern Brazil, from Rio de Janeiro to Rio Grande do Sul State, Uruguay and Argentina, including Patagonia. It inhabits the continental shelf, from 10 to 170 meters depth, where it generally lives in mud, sand and shell bottom (Melo, 1996). The knowledge of this species is almost restricted to its biogeography (Boschi, 2000; Braga et al., 2005) and studies concerning its ecology and population biology are scarce in the literature.

In this study, our purposes is to detail some population features of $L$. tuberculosus sampled as bycatch during the pink shrimp fishery, as their population structure, fecundity and relative growth in the coast of the Rio de Janeiro State, Southeast Brazil.

\section{Material and Methods}

\section{Study area}

The coast of Rio de Janeiro State is part of Southeast Continental Shelf. The ocean in this area is characterized by a mix of the Tropical Water of the Brazil Current or South Atlantic Central Water and costal water with continental influence. The dynamics of this mass of water has consequences to the climate, resulting in a great difference between summer and winter (Figueiredo Jr. and Madureira, 2004). Specifically for the coast of Rio de Janeiro, there is a predominance of warm (temperature higher than $\left.18^{\circ} \mathrm{C}\right)$, saline $(36$ $\mathrm{psu}$ ), and oligotrophic tropical water that is transported by the Brazil Current in the South and Southwest way (Bizerril and Costa 2001). In areas close to the sample site, the substrate is mainly composed by sand and gravelly sand (Figueiredo Jr and Madureira, 2004).
The samples were taken as bycatch from pink-shrimps trawling along the coast of the Rio de Janeiro State $\left(23^{\circ} 01^{\prime} 075^{\prime \prime} \mathrm{S}\right.$ $23^{\circ} 06.314^{\prime} \mathrm{S}$ to $\left.42^{\circ} 23^{\prime} 117^{\prime \prime} \mathrm{W}-43^{\circ} 32.950^{\prime} \mathrm{W}\right)$ performed by a typical commercial shrimp boat in October (2008), February (2009), June (2009) and September (2009). Trawling lasted about four hours and occurred between depths of 43 and $61 \mathrm{~m}$. After the trawling, the L. tuberculosus specimens were screened on the boat deck and taken to the laboratory where they were frozen. In the laboratory, the crabs were sexed and the following biometric measures were taken using a vernier calliper $(0.01 \mathrm{~mm})$ : carapace width $(\mathrm{CW})$, carapace length (CL), right and left cheliped propodus length (RCL, LCL), right and left cheliped propodus height $(\mathrm{RCH}, \mathrm{LCH})$; abdomen width (AW) for females and gonopod length (GL) for males. Ovigerous female had their individual fecundity estimated through the volumetric method (Díaz et al., 1983). These females had their egg mass with the pleopods removed and immersed for some seconds in a solution of sodium hypochlorite $(70 \%)$ for eggs dissociation and quickly washed in tap water. After that, the eggs were taken into a Becker, supplementing the volume to $50 \mathrm{ml}$. After homogenization, five sub-samples of 1 $\mathrm{ml}$ each were taken (with reposition) and the eggs counted using a stereoscopic microscopic. The average of the five sub-samples was performed to estimate the individual fecundity. The egg's embryonic stage of development was delimited: Stage I - freshly extruded egg mass sponge, large quantity of yolk filing all egg volume; Stage II - large quantity of yolk, marginal areas of the eggs without yolk fill; Stage III - compound eyes of the larvae are differentiated, the embryo occupies $1 / 3$ of the volume of the egg and the segmentation is not visible; Stage IV - the larvae is totally formed, the segmentation is well visible.

\section{Data analysis}

The individuals were distributed in twenty nine CW classes of $2 \mathrm{~mm}$ amplitude each, ranging from 12 to $72 \mathrm{~mm}$, for the recognition of different age classes through 
the modal frequency distribution. The sex ratio significance was tested using the ChiSquare test $(\alpha=0.05)$ into each CW size class. The size at maturity was determined as an allometric discontinuity in the growth of CW relative to AW for females and to GL, RCL and LCL for males, detected by breakpoint (BP) regression analysis using the software REGRANS (Pezzuto, 1993). Additionally, ANCOVA $(\alpha=0.05)$ was employed in order to confirm the significance in the allometry changes in both regressions originated from the breakpoint analysis. The linear regression [egg number $(E N)=a+b(C W, A W)]$ and the Pearson's correlation index $(\mathrm{r})$ were employed to verify the correlation between fecundity and CW or AW. Analysis of relative growth were performed to describe the growth ratio of the reference measure $(\mathrm{CW})$ and the dependent variables $(y)$ through the logarithmic form (log $y=\log a+b \log (W)$ of the power function $y=a b^{C W}$ (Hartnoll, 1978). The Student's T test $(\alpha=0.05)$ was used to test the significant deviation of the allometric constant (b) from 1 , determining the isometric or allometric condition between CW and the dependent variables.

\section{Results}

A total of 269 crabs, 168 males and 101 females (42 ovigerous) were sampled during the trawling. Male crabs attained the largest CW classes (Fig. 1). They were most frequent in the class of $58-60 \mathrm{~mm}$ while females were most frequent in the $38-40 \mathrm{~mm}$ CW class. The CW of males ranged from 12.81 to $71.67 \mathrm{~mm}$ (mean \pm SD: $48.77 \pm 13.75 \mathrm{~mm}$ ). In females, CW ranged from 15.33 to $55.44 \mathrm{~mm}$ (36.19 $\pm 8.66 \mathrm{~mm})$. The overall sex ratio was $1: 1.66$ $(\mathrm{M}: \mathrm{F})$ and differed statistically $\left(\mathrm{X}^{2}=16.68\right.$; $\mathrm{p}>0.05)$ from the expected (1:1). In the size classes (CW) from $50-52 \mathrm{~mm}$, males were predominant (Fig. 2).

In females, the morphometric relationship CW $\mathrm{x}$ AW was reliable and displayed two distinct phases of allometric growth corresponding to juveniles and adults (Fig. 3). The breakpoint (size at maturity) was estimated in $30.0 \mathrm{~mm}(\mathrm{~F}=0.756, \mathrm{p}<0.05)$ and the ANCOVA confirmed the change in the allometry from the resultant equations. In males, the morphometric relationships displayed different breakpoints (BP): a) CW $x$ LCL: $\mathrm{BP}=61.18(\mathrm{~F}=7.182 ; \mathrm{p}>0.05)$; $\mathrm{b}) \mathrm{CW}$

Table I. Leurocyclus tuberculosus. Relative growth between $\mathrm{CW}$ and the dependent variables $\left(\mathrm{n}=\right.$ sample size; $\mathrm{r}=$ correlation coefficient; $\mathrm{R}^{2}=$ determination coefficient; $\mathrm{a}=$ intercept axis; $\mathrm{b}=$ allometric constant; $\mathrm{AL}=$ allometry; $\left(^{*}\right)=$ significant difference $(\mathrm{p}<0.05)$; $\mathrm{CW}=$ carapace width; $\mathrm{CL}$ = carapace length; $\mathrm{RCL}=$ right cheliped length; $\mathrm{RCH}=$ right cheliped height; $\mathrm{LCL}=$ left cheliped length; $\mathrm{LCH}=$ left cheliped height; $\mathrm{GL}=$ gonopod length; $\mathrm{AW}=$ abdomen width).

\begin{tabular}{|c|c|c|c|c|c|c|c|}
\hline \multirow{2}{*}{ Regression } & \multicolumn{6}{|c|}{ MALES } & \multirow[b]{2}{*}{ AL } \\
\hline & $\mathbf{n}$ & $\mathbf{r}$ & $\mathbf{R}^{2}$ & $\mathbf{a}$ & b (I.C. 95\%) & $\mathbf{t}(\alpha=0.05)$ & \\
\hline $\mathrm{CW} \times \mathrm{CL}$ & 168 & 0.990 & 0.981 & 0.029 & $0.944(0.99-0.96)$ & $-5.59^{*}$ & - \\
\hline CW x RCL & 145 & 0.975 & 0.950 & -0.688 & $0.975(1.15-1.24)$ & $-1.58^{*}$ & + \\
\hline $\mathrm{CW} \times \mathrm{RCH}$ & 145 & 0.919 & 0.845 & -1.687 & $1.557(1.44-1.66)$ & $17.40^{*}$ & + \\
\hline CW x LCL & 157 & 0.910 & 0.828 & -0.719 & $1.223(1.13-1.31)$ & $6.75^{*}$ & + \\
\hline $\mathrm{CW} \times \mathrm{LCH}$ & 157 & 0.957 & 0.916 & -1.784 & $0.957(1.50-1.65)$ & $-1.86^{*}$ & + \\
\hline \multirow[t]{2}{*}{ CW x GL } & 167 & 0.967 & 0.935 & -0.404 & $0.967(0.89-0.97)$ & $-1.73^{*}$ & - \\
\hline & \multicolumn{6}{|c|}{ FEMALES } & \\
\hline $\mathrm{CW} \times \mathrm{CL}$ & 100 & 0.980 & 0.961 & -0.029 & $0.991(0.95-1.03)$ & $-0.47^{*}$ & - \\
\hline CW x RCL & 90 & 0.976 & 0.952 & -0.292 & $0.915(0.87-0.95)$ & $-3.69^{*}$ & - \\
\hline $\mathrm{CW} \times \mathrm{RCH}$ & 90 & 0.953 & 0.908 & -0.825 & $0.921(0.85-0.98)$ & $-2.46^{*}$ & - \\
\hline CW $x$ LCL & 93 & 0.976 & 0.954 & -0.315 & $0.927(0.88-0.96)$ & $-3.31^{*}$ & - \\
\hline $\mathrm{CW} \times \mathrm{LCH}$ & 93 & 0.939 & 0.832 & -0.809 & $0.912(0.84-0.98)$ & $-2.51^{*}$ & - \\
\hline CW x AW & 99 & 0.939 & 0.881 & -1.171 & $1.594(1.47-1.71)$ & $17.47^{*}$ & + \\
\hline
\end{tabular}


x RCL: $\mathrm{BP}=37.0 \mathrm{~mm}(\mathrm{~F}=12.997, \mathrm{p}>0.05)$; c) $\mathrm{CW} \times \mathrm{GL}: \mathrm{BP}=55.0 \mathrm{~mm}(\mathrm{~F}=2.015, \mathrm{p}<$ 0.05). According to ANCOVA, only CW x GL confirmed changes in allometry between the two regressions resultant from the breakpoint. This way, this morphometric relationship was used to state the size at maturity in males (55.0 $\mathrm{mm}$ ) (Fig. 3).

The relative growth analysis (Tab. I) showed differences in the growth of the chelipeds between males and females. Male crabs showed positive allometry in RCL, LCL, $\mathrm{RCH}$ and $\mathrm{LCH}$ while female showed negative allometry in these measures. The relationship between $\mathrm{CW}$ and GL showed negative allometry (males) while the relationship between $\mathrm{CW}$ and AW showed positive allometry (females). Males and females showed very close values of allometry (negative) in the relation between CW and CL.

The individual fecundity ranged from 3,450 to 23,680 eggs/brood (10,327.3 \pm 4,827.7) (Tab. II). The equations obtained through the linear regression between fecundity and CW and AW were, respectively, $\mathrm{EN}=7.91 \mathrm{CW}-124.99(\mathrm{r}=0.691 ; \mathrm{p}>0.05)$ and $\mathrm{EN}=13.56 \mathrm{AW}-146.49(\mathrm{r}=0.393 ; \mathrm{p}$ $>0.05)$. Table IV shows the fecundity in the embryonic stages.

Table II. Leurocyclus tuberculosus. Fecundity by embryonic stages in the coast of the Rio de Janeiro State $(\mathrm{n}=$ sample size; $\mathrm{SD}=$ Standard deviation).

\begin{tabular}{cccccc}
\hline \multirow{2}{*}{ Stages } & \multirow{2}{*}{$\mathbf{c}$} & \multicolumn{4}{c}{ Fecundity } \\
\cline { 3 - 6 } & & Mean & Min. & Max. & SD \\
\hline I & 8 & 175.8 & 72.2 & 280.6 & 46.8 \\
\hline II & 14 & 225.6 & 160 & 473.6 & 51.2 \\
\hline III & 4 & 257.5 & 158.4 & 431.2 & 64.0 \\
\hline IV & 2 & 89.2 & 69 & 109.4 & 13.9 \\
\hline
\end{tabular}

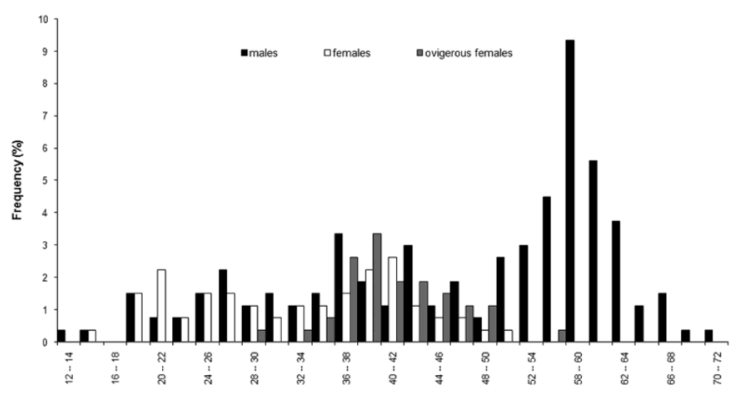

Figure 1. Leurocyclus tuberculosus. Relative frequency of males, females and ovigerous females of in the coast of the Rio de Janeiro State.

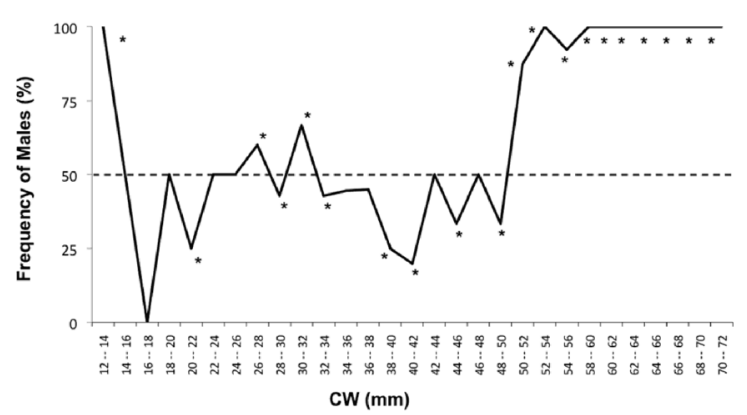

Figure 2. Leurocyclus tuberculosus. Sex ratio as a function of size in the Rio de Janeiro coast. The asterisk means significant deviations from the expected (1:1) sex ratio $(\alpha=0,05)$.
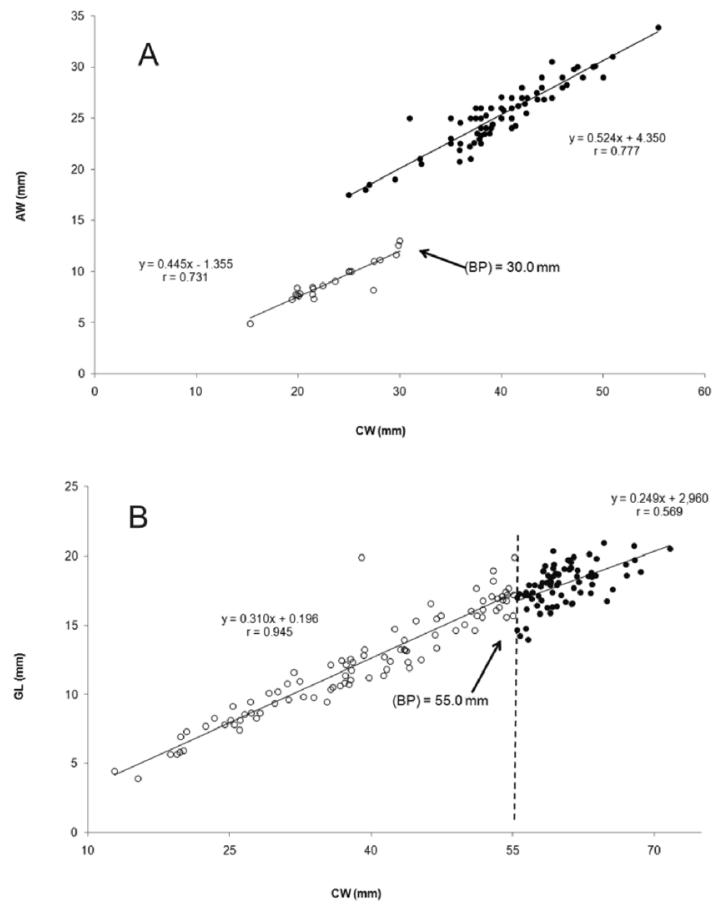

Figure 3. Leurocyclus tuberculosus. Regression lines fitted to data from morphologically immature and mature females (A) and males (B). (CW = carapace width; AW = abdomen width; GL = gonopodus lenght; $(\mathrm{BP})=$ breakpoint; Open circles = immature individuals; Dark circles $=$ mature individuals $)$.

\section{Discussion}

In brachyuran crustaceans, the differential growth between sexes is due to the differential energy allocation (Hartnoll, 1982). While males use their energy mainly for growth in size, becoming more attractive for mating, females expend more energy in gonadal maturation and egg production besides not moulting during the egg incubation. The Figure 2 illustrates a predominance of males in the largest CW classes (from 50 to $52 \mathrm{~mm}$ until 70 to $72 \mathrm{~mm}$ ). The size of the crabs when it 
attains the sexual maturity also varied between sexes. Females attain the sexual maturity (CW $=30.0 \mathrm{~mm}$ ) faster than males $(55.0 \mathrm{~mm}$ ) (Fig. 3). Probably, the differential size at maturity between sexes is a result of the strategies above described. Controversially, Barón et al. (2009) in the Patagonian gulfs, found more similar results of size at maturity for females $(\mathrm{CW}=$ $47.9 \mathrm{~mm}$ ) and males $(\mathrm{CW}=48.9 \mathrm{~mm})$ of $L$. tuberculosus.

The difference between the females in the size at maturity corroborated the tendency of crabs in higher latitudes to mature in larger sizes (Hines, 1989) that was also reported for other majoid species as Chionoecetes bairdi Rathbun, 1924 and C. opilio (Frabricius, 1788) (Somerton, 1981). Otherwise, the difference in male size at onset of sexual maturity is possibly due to the difference in the measures used. In Patagonian gulfs, the cheliped length has revealed the breakpoint that shows the size at maturity. In the present work, this measure was not statistically reliable and the gonopod length was used, what could cause the bigger result.

Hartnoll (1974) describes a pattern for the relative growth in Brachyura that is corroborated by some of the results of the present work. The positive allometry for the male chelipeds and female abdomen width was common to his predictions and, probably, indicates adaptations for sexual behaviour and eggs incubation. Hartnoll's prediction (1974) for the gonopod length growth was not corroborated in the present study. According to this author, the gonopods have changes in growth between immature and mature crabs, presenting positive allometry before the puberty moult and negative after it. However, in the present study, which did not distinguish the male as adult or immature, this relationship showed positive allometry.

According to the Pearson's index ( $\mathrm{p}>$ $0.05)$, the equations obtained from the linear regression between the individual fecundity and CW or AW were positive correlated. However, CW fit better with egg number $(r=0.691)$ than AW $(r=0.393)$. This way, it is in accordance with the prediction that body size in crustaceans is directly related with the eggs production (Hines, 1982). The low Pearson's index found in the EN $x$ AW relationship was probably due to the different stages of embryonic development of the ovigerous females analysed. The mix of eggs in all stages of development probably decreased the correlation index. The choice to use all females in the same analysis, in spite the different embryonic stages from its eggs, was taken into account the low number of females bearing eggs in the last stage $(n=2)$ and the predominance of females with eggs in intermediate stages.

The relative frequency of $L$. tuberculosus in the present study (Fig. 1) shows that the trawling activity is exercising a large influence in this population in the Rio de Janeiro coast, where since young $(\mathrm{CW}=12$ to $14 \mathrm{~mm}$ ) from old crabs (CW $=70$ to $72 \mathrm{~mm}$ ) are accidently captured. This way, young crabs are removed from its habitat and discharged before attaining the sexual maturity (and, consequently, before reproducing) and the adults leave precociously the population increasing the mortalities rates. Taking into account the development and frequency of the pink shrimp fishery in the Rio de Janeiro coast, we conclude that the interference of the trawling in the $L$. tuberculosus populations is meaningful. The crabs condition (many chelipeds and legs broken) after the trawl is precarious and the majority arrives dead to the vessel. In these conditions, the release of the still alive crabs to the sea do not guarantees the survival and return of the crabs to the natural population. In a general form, the survival of the crabs captured during the trawling is minimal.

The bycatch in shrimp trawl is composed by several zoological groups, especially fishes, molluscs and other crustaceans (Loebmann and Vieira, 2006; Graça-Lopes et al., 2002; Vianna and Almeida, 2005). According to Davies et al. (2009), the bycatch in Brazil has a ratio of $8.9 \mathrm{~kg}$ of discard to $1 \mathrm{~kg}$ of target species and only $10 \%$ is commercial. The bycatch of $L$. tuberculosus in trawling activities is reported in Rio de Janeiro and São Paulo States, Southeast Brazil (Keunecke et al., 2007; Puciarelli, 2010), 
and in San Jorge Gulf, coast of Chubut and Santa Cruz provinces, in Argentina (Roux and Piñero, 2006), both in shrimp fishery, and also in the North-Eastern zone of the Uruguayan continental shelf, in mollusk fishery (Riestra et al., 2006).

Leurocyclus tuberculosus was captured during the trawl in depth ranged from 31 to 51 $\mathrm{m}$ in Sáo Paulo State (Keunecke et al., 2007) and from 30 to $70 \mathrm{~m}$ in Uruguay (Riestra et al., 2006), covering a similar bathymetric profile. In both cases, L. tuberculosus was not an abundant species and Riestra et al. (2006) refer to it as a scarce species. Controversially, the research in Argentina and Rio de Janeiro, L. tuberculosus was one of the most captured species. According to Puciarelli (2010), L. tuberculosus is the third most captured species in the coast of the Rio de Janeiro State. Considering the high index of capture, Roux and Piñero (2006) conclude that $L$. tuberculosus is included in a group of species closely related to sectors with high fishing intensity and considered as a typical bycatch in shrimp fishery.

\section{Acknowledgments}

We thank Professor Dr. Marcelo Vianna and the biologist Pedro Puciarelli de Melo from the "Laboratorio de Biologia e Tecnologia Pesqueira" - Departamento de Biologia Marinha/IB/UFRJ, responsible for collecting the studied material. Also we would like to thank the reviewers for their helpful comments on the manuscript.

\section{References}

Alverson, D.L.; Freeberg, M.H.; Murawski, S.A. and Pope, J.G. 1994. A global assessment of the fisheries by-catch and discards. FAO Technical Paper, 339p.

Barón, P.J.; Quiroga, A.P.; Leal, G.A. and González-Pisani, X. 2009. Morphological maturity of the knobbed spider crab,
Leurocyclus tuberculosus (H. Milne Edwards \& Lucas, 1842) (Brachyura, Majidae) in the Northern Patagonian Gulfs. Crustaceana, 82(3): 267-273.

Bizerril, C.R.S.F. and Costa, P.A.S. 2001. Peixes marinhos do estado do Rio de Janeiro. Rio de Janeiro: FEMAR. 234 p.

Boschi, E.E. 2000. Species of decapod crustaceans and their distribution in the American Marine Zoogeographic Provinces. Revista de Investigación y Desarollo Pesquero, 13: 7-136.

Braga, A.A.; Fransozo, A.; Bertini, G. and Fumis, P.B. 2005. Composição e abundância dos caranguejos (Decapoda, Brachyura) nas regióes de Ubatuba e Caraguatatuba, litoral norte paulista, Brasil. Biota Neotropica, 5(2): 1-34.

Brasil. Portaria MMA n ${ }^{\circ} 74$, de 13 de fevereiro de 2001. Proíbe, no período de $1^{\circ}$ de março a 31 de maio, a pesca de arrasto motorizado de camarão-rosa (Farfantepenaeus paulensis, Farfantepenaeus brasiliensis e Farfantepenaeus subtilis), camarão-sete-barbas (Xiphopenaeus kroyeri), camarão-branco (Litopenaeus schmitti), camarão-santana (Pleoticus muelleri), e camarão-barba-ruça (Artemesia longinaris), na área compreendida entre os paralelos 18²0'S (divisa dos Estados da Bahia e Espírito Santo) e 33040'S (Foz do Arroio Chuí, Estado do Rio Grande do Sul). In: Diário Oficial da União, Brasília, DF, 15 fev 2001.

Brasil. Portaria SUDEPE ${ }^{\circ}$ N-26, 28 de julho de 1983. Define critérios técnicos para o exercício de pesca com utilização de redes de arrasto. In: Diário Oficial da União, Brasília, DF, 02 ago 1983.

Brasil. Portaria SUDEPE no N-55, de 20 de dezembro de 1984. Determina critérios para a pesca do camarão-rosa (Penaeus brasiliensis e Penaeus paulensis) e do camarão verdadeiro (Penaeus schmitti) nas regiōes Sul e Sudeste do Brasil. In: Diário Oficial da União, Brasília, DF, 26 dez 1984.

Castello, L. 2008. Repensando o estudo e o manejo da pesca no Brasil. Pan-American Journal of Aquatic Sciences, 3(1): 17-22.

Figueiredo Jr, A.G. and Madureira, L.S.P. 
2004. Topografia, composição, refletividade do substrato marinho e identificação de províncias sedimentares na Região Sudeste-Sul do Brasil. Série Documentos Revizee - Score Sul. São Paulo: Instituto Oceanográfico/USP. 64p.

Hartnoll, R.G. 1974. Variation in growth pattern between some secondary sexual characters in crabs (Decapoda Brachyura). Crustaceana, 27(2): 131-136.

Hartnoll, R.G. 1978. The determination of relative growth in Crustacea. Crustaceana, 34 (3): 281-293.

Hartnoll, R.G. 1982. Growth. p. 111-196. In: Abele, G. (ed), The biology of Crustacea - embryology, morphology and genetics. London, London Academic Press, 440p.

Hines, A.H. 1982. Allometric constraints and variables of reproductive effort in brachyuran crabs. Marine Biology, 69: 309320.

Hines, A.H. 1989. Geographic variation in size at maturity in brachyuran crabs. Bulletin of Marine Science, 45(2): 356-368.

Keunecke, K.A; Vianna, M; Fonseca, D.B. and D'Incao, F. 2007. The pink-shrimp trawling bycatch in the northern coast of Sáo Paulo, Brazil, with emphasis on crustaceans. Nauplius, 15(2): 49-55.

Melo, G.A.S. 1996. Manual de identificação dos Brachyura (caranguejos e siris) do litoral brasileiro. São Paulo, Plêiade. 604p.

Pauly, D.; Christensen, V. and Guénette, S. 2002. Towards sustainability in world fisheries. Nature, 418: 689-695.

Pezzuto, P.R. 1993. Regrans: a "basic" program for an extensive analysis of relative growth. Atlântica, 15: 93-105.

Puciarelli, P. 2010. Carcinofauna acompanhante na pescaria industrial do camarão-rosa e estrutura populacional de Achelous spinicarpus (Stimpson, 1871) (Crustacea,Decapoda, Portunidae) nolitoral fluminense, Brasil. Trabalho (Graduação). Instituto de Biologia, Departamento de Biologia Marinha, Universidade Federal do Rio de Janeiro, 2010.

Riestra, G; Lozoya, J.P; Fabiano G; Santana O. and Carrizo, D. 2006. Benthic macroinvertebrate bycatch in the snail Zidona dufresnei (Donovan) fishery from the Uruguayan continental shelf. PanAmerican Journal of Aquatic Sciences, 1(2): 104-113.

Roux, A. and Piñero, R. 2006. Crustáceos decápodos y estomatópodos asociados a la pesquería Del langostino patagônico Pleoticus muelleri (Bate, 1888) en El golfo San Jorge, Argentina. Revista de Investigación y Desarollo Pesquero, 18: 33-43.

Silva, O.A.O. and Viana, M. 2009. A produção pesqueira do Estado do Rio de Janeiro. In: Vianna, M. (ed), Diagnóstico da cadeia produtiva da pesca marítima no Estado do Rio de Janeiro: relatório de pesquisa. Rio de Janeiro, FAERJ: SEBRAE-RJ.

Somerton, D.A. 1981. Regional variation in the size of maturity of two tanner crab (Chionoecetes bairdi and Chionoecetes opilio) in the bering Sea, and its use in definig management subareas. Canadian Journal of Fishery and Aquatic Sciences, 38:136-174. 